\title{
Penentuan Pakan Rusa Bawean dengan Analisis Kotoran, di Pulau Bawean
}

\author{
Using Fecal Analysis to Identify Food of Bawean Deer in Bawean Island
}

Djuwantoko* dan Danang Wahyu Purnomo

Laboratorium Satwa Liar Fak. Kehutanan Universitas Kehutanan Universitas Gadjah Mada, Yogyakarta E-mail: juwantoko@yahoo.com*Penulis untuk korespondensi

\begin{abstract}
The research was conducted in the Bawean island, East Java, where endemic Bawean deer's inhabited naturally. The objective was to assess what kind of plant species as food resources in natural habitat of Bawean deer. The most Bawean deer habitats particularly lowland forests, are under the greatest pressure. Logging and land conversion have caused dramatic decreases in the forest cover of Bawean island, mainly in lowland, and forest margins are progressively shifting towards higher elevations. In that conditions, therefore a management practices should be implemented soon, for improving deer habitat. This study was focused on availability of food resources in the natural habitat of Bawean deer. Using indirect methods in the field to assess the remaining of food resources, which was consumed by Bawean deer, and fecal analysis was executed for identifying food deer items. The result, there were many species of plants as a food resources including Imperata cylindrical (lalang), Pericampylus glaucus (ancucu), Caryota mitis (andudur), Discorea hispida (gadung), Symplocos adenophylla (kayu sape), Coelorhachis muricata (lampedung), Scheria hebecarpa (lanting-lantingan), Paspalum cunyugatum (lambu merah), Argyera mollis (rombok putih), Lygodium circinnatum (taliata), Nephrolepis hirsitula (rendingrendang), Tridax procumbens (kenci-kencian), Brachiaria distachya (kabak-kabakan alas), Frimbrisyllis dichotoma (lente-lentean). The availability of those food resources was affected by season i.e., dry and rainy season, and the feeding habit of Bawean deers can allow adapting to the habitat condition. Based on that figure the Bawean deers may have so many several of food items in their natural habitat.
\end{abstract}

Key words: Bawean deer (Axis kuhlii), fecal analysis, Bawean island food resource

Diterima: 21 April 2008, disetujui: 23 Agustus 2008

\section{Pendahuluan}

Pakan sebagai salah satu unsur habitat penting bagi rusa, menentukan kelimpahan dan sebarannya (Jacques et al., 2006; Graham, 2002; Benson, 2003). Oleh karena itu, perbaikan habitat rusa melalui gatra pakan dan penentuan jenis-jenis tumbuhan pakannya perlu dilakukan (Gray et al., 2007; Jacques et al., 2006; Mcinnis et al., 1983; Junsheng et al., 2008).

Studi di lapangan oleh BKSDA Jatim I (Anonim, 2003a) terdapat berbagai kendala, yaitu sulitnya menemukan satwa rusa Bawean.
Tampaknya satwa ini peka oleh adanya gangguan terhadap habitatnya. Menghadapi keadaan itu diperlukan cara pengamatan tidak langsung, seperti pengamatan bekas atau sisa gigitan pakan dan analisis kotoran. Kelebihan metode ini tanpa mengganggu perilaku kehidupannya (Kurose et al., 2005; Junsheng et al., 2008). Analisis kotoran, dapat pula dimanfaatkan menaksir populasi rusa Bawean (Blouch dan Atmosoedirdjo, 1978; Hansen et al., 2001).

\section{Tipe habitat Rusa Bawean}

Satwa dalam usaha untuk mencapai kehidupan optimal, melakukan perilaku sesuai 
dengan habitatnya, dengan mewujudkan perilaku ekologi (Atle et al., 2001; Bolen dan Robinson, 1995). Habitat rusa Bawean dapat dikelompokan menjadi empat macam, yaitu: kelompok hutan sekunder, kelompok hutan primer, kelompok hutan tanaman jati bersemak (tumbuhan bawah); dan hutan campuran (Anonim, 2003a). Tipe hutan sekunder memiliki tumbuhan pakan yang melimpah, sehingga paling banyak dimanfaatkan oleh rusa Bawean (Anonim, 2003a). Pemanfaatan tipe-tipe habitat diketahui dengan identifikasi tanda-tanda kehadiran rusa pada setiap tipe habitat (Anonim, 2003b).

\section{Pakan Rusa Bawean}

Menurut Blouch dan Atmosudirdjo (1978), rusa Bawean memakan berbagai jenis tumbuhan, perilaku ini sesuai dengan habitatnya yang berupa aneka ragam tipe habitat. Berbagai tipe habitat tersebut, jelas mampu menyediakan aneka jenis sumber pakan bagi rusa Bawean. Aneka jenis sumber pakan rusa berupa tunas-tunas muda dari berbagai jenis tumbuhan seperti tunas rumput, tunas herba, tunas semak-semak, liana, pohon, ataupun lumut-lumut, ataupun epipit (Anonim, 2003a).

\section{Analisis kotoran (Fecal Analysis)}

Analisis kotoran dilakukan dengan pengujian mikroskopis pecahan-pecahan (fragments) tumbuhan dimakan satwa, yang tertinggal di dalam kotoran (Padmalal et al., 1993; Djuwantoko, 1994; Jacques et al., 2006). Cara ini mencakup dua hal pokok yaitu, koleksi dan analisis berbagai jenis tumbuhan yang dimungkinkan dimakan satwa, kemudian identifikasi pecahan-pecahan epidermis dalam kotoran satwa (Takatsuki, 1978; Junsheng et al., 2008; Padmalal et al., 1993; Djuwantoko, 1994).

Sebagai obyek analisis adalah hasil pertumbuhan kutikula, yaitu suatu lapisan kontinyu dari permukaan paling luar tunastunas tumbuhan, yang dibentuk oleh polimerisasi substansi lemak tidak jenuh (Hercus, 1960). Selanjutnya kutikula keluar melalui kotoran, tanpa mengalami perubahan terkecuali ukuran, karena perlakuan mekanis dalam sistem pencernaan satwa (Kurose et al.,
2005; Padmalal et al., 1993; Junsheng et al., 2008).

\section{Metode Penelitian}

\section{Bahan dan Alat}

Bahan-bahan yang diperlukan adalah kotoran rusa Bawean dan koleksi beberapa jenis daun dari tumbuhan di lokasi pengamatan. Koleksi diambil dari tempat-tempat yang diduga kuat sebagai sumber pakan Rusa Bawean. Analisis kotoran diperlukan beberapa bahan kimia antara lain: larutan asam nitrat (HNO3) 10\%, potasium kromat (K2CrO4) 10\%, alkohol 70\%, gliserin, xylol, parafin, dan aquades. Peralatan lapangan seperti Geographical Position System (GPS), untuk memetakan titik-titik pengambilan cuplikan (sample), dan selain itu juga diperlukan berbagai alat laboratorium.

\section{Cara Penelitian}

Identifikasi jenis pakan rusa dilakukan pengamatan di lapangan dan dilanjutkan analisis kotoran rusa di laboratorium. Sebagai laboratorium digunakan Laboratorium Satwa Liar, Fakultas Kehutanan Universitas Gadjah Mada, Yogyakarta. Pengamatan di lapangan menggunakan metode jalur. Lokasi pengamatan adalah di kawasan Suaka Alam dan Pulau Tanjung Cina, di Pulau Bawean (Gambar 1). Panjang masing-masing jalur 1000m (1 km). Penempatan jalur di lapangan dilakukan secara acak, dengan pertimbangan hambatan dan kondisi lapangan. Plot-plot pengamatan berbentuk lingkaran dengan jarijari 11,3 m, secara kontinyu, sepanjang garis jalur. Jenis-jenis tumbuhan yang teridentifikasi sebagai pakan rusa dicatat dan dibuat herbarium. Diamati pula bagian-bagian dari tumbuhan yang dimakan dan kondisi tumbuhan secara umum. Kotoran rusa yang diketemukan sepanjang jalur dikumpulkan dan diawetkan untuk keperluan analisis kotoran. Prosedur analisisnya adalah sebagai berikut (Bhadresa, 1981; David, 1962): 


\section{Pembuatan preparat awetan kotoran Rusa Bawean}

Dilakukan dengan Metode Penghancuran Asam Nitrat (HNO3) atau Nitric Acid Digestion Method (Storr, 1961), sebagai berikut: 1) Kotoran dikeringkan dalam oven pada suhu $70^{\circ} \mathrm{C}$, selama 2 X 24 jam hingga kering. 2) Kotoran yang telah kering kemudian ditumbuk halus. 3) Kemudian kotoran halus diambil seberat 1,5 gram dan dimasukkan ke dalam gelas beker yang berisi $20 \mathrm{ml}$ lauran Asam Nitrat (HNO3) 10\% dan $20 \mathrm{ml}$ Potasium Kromat (K2Cr2O4) 10\%. 4) Gelas beker yang berisikan larutan tersebut kemudian dipanaskan di atas lampu spiritus selama kurang lebih 10 hingga 15 menit. 5) Larutan tersebut kemudian dinetralkan dengan Aquades, setelah terlebih dahulu didinginkan. 6) Larutan netral ditandai dengan kenampakan yang transparan, kemudian larutan tersebut dipindahkan ke dalam cawan petri (petridis) untuk dipanaskan hingga kental sekali. 7) Ke dalam cawan petri ditambahkan $15 \mathrm{ml}$ alkohol 70\%, agar menjadi bahan preparat awetan. 8) Larutan tersebut diambil 0,1 $\mathrm{ml}$ dengan pipet atau dengan spatula untuk dioleskan dalam gelas benda (objeck glass). 9) Olesan larutan pada gelas benda tersebut kemudian dikeringkan, kemudian ditetesi dengan gliserin, dan xylol, kemudian ditutup dengan gelas penutup (cover glass). Preparat awetan telah siap diuji di bawah mikroskop, dan dapat disimpan untuk beberapa waktu sebelum diamati (Stewart, 1967; Storr, 1961).

\section{Pembuatan preparat epidermis}

Pembuatan preparat epidermis tumbuhan pakan hampir sama dengan pembuatan preparat kotoran Storr (1961), yaitu: 1) Daun dikeringkan dalam oven selama 1 X 24 jam dalam suhu $70^{\circ} \mathrm{C}$. 2) Membuat potongan daun sebesar 2 X $2 \mathrm{~cm}$ pada bagian yang memiliki urat daun, untuk mempermudah membedakan permukaan atas dan bawah daun. 3) Potongan daun kemudian dimasukkan ke dalam larutan campuran $10 \mathrm{ml}$ Asam Nitrat (HNO3) 10\% dan $10 \mathrm{ml}$ Posasium Kromat (K2CrsO4)10\%. Selanjutnya larutan dipanaskan selama kurang lebih 5 sampai dengan 10 menit, atau sampai klorofil daun hilang. 4) Larutan kemudian dinetralkan dengan aquades, kemudian ditambah alkohol $70 \%$ dan zat pewarna safranin. 5) Epidermis diletakkan di atas gelas benda, kemudian diteteskan gliserin dan xylol. Setelah itu gelas benda ditutup dengan gelas penutup. Preparat epidermis siap diamati di bawah mikroskop dengan perbesaran 125 kali.

Preparat kemudian diamati di bawah mikroskop sampai diperoleh penampakan epidermis yang jelas. Gambar epidermis direkam dengan kamera digital yang dihubungkan dengan komputer. Gambar ini selanjutnya digunakan sebagai kunci identifikasi untuk menentukan jenis tumbuhan yang terdapat di dalam kotoran Rusa Bawean.

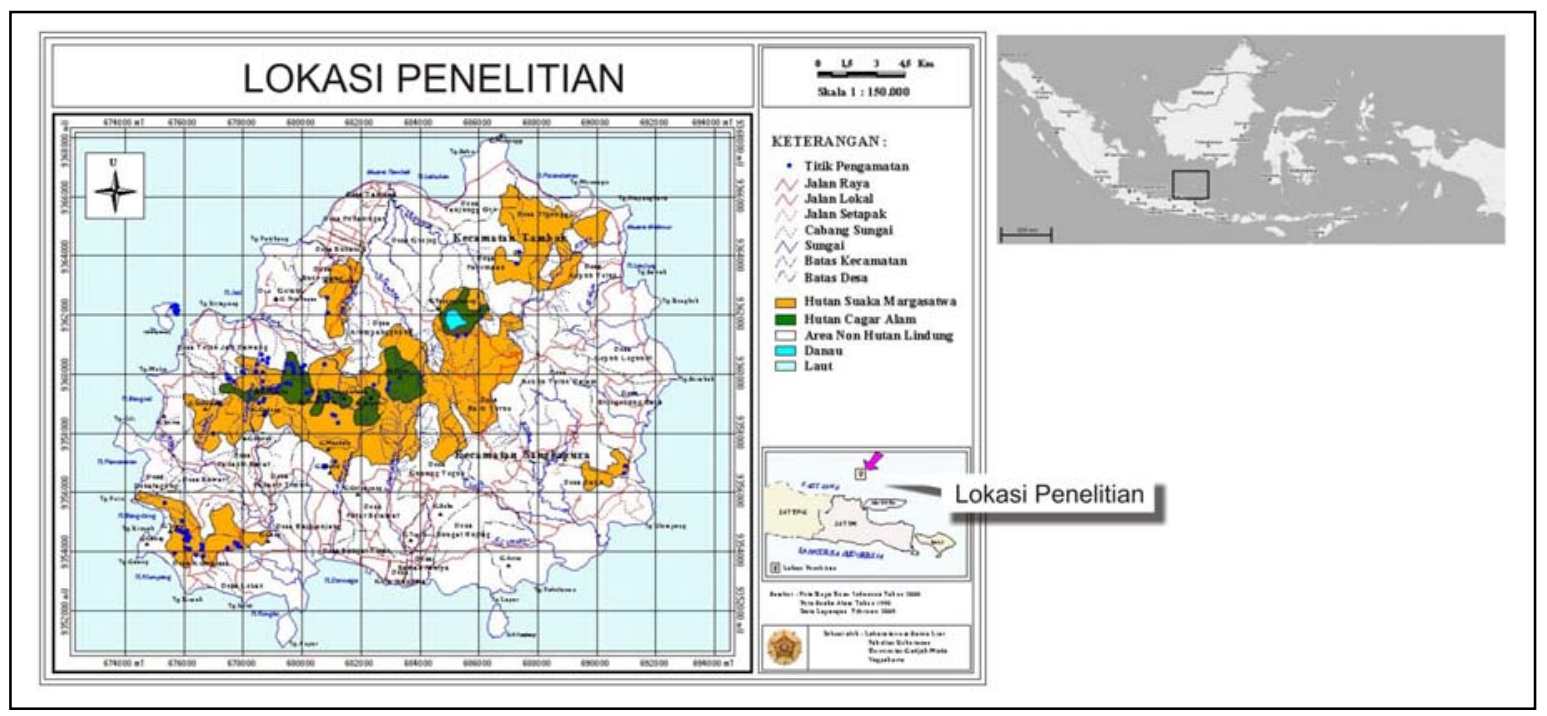

Gambar 1. Peta Lokasi Penelitian. 


\section{Kuantifikasi}

Kuantifikasi dilakukan dengan cara: 1) Mengestimasi fragment epidermis yang terdapat dalam kotoran untuk estimasi komposisi pakan yang ada di dalamnya. 2) Mengestimasi luas permukaan dari masingmasing pecahan epidermis. 3) Setiap cuplikan kotoran dibuat tiga preparat, yang masingmasing preparat diamati melalui lima buah titik pandang. Perbesaran Pengamatan 125 kali.

Jenis-jenis tumbuhan pakan yang didapatkan dianalisis mengenai nama ilmiah dan taksonominya. Nama daerah suatu jenis pakan dapat diperoleh dari informasi petugas atau masyarakat setempat. Selanjutnya dilakukan studi referensi dengan referensi utama adalah Tumbuhan Berguna Indonesia (Heyne, 1987).

\section{Hasil dan Pembahasan}

\section{Identifikasi pakan di lapangan}

Berdasarkan pengamatan di lapangan, informasi dari masyarakat setempat dan juga dari petugas KSDA (Konservasi Sumber Daya Alam) Pulau Bawean, dapat diidentikasi beberapa jenis tumbuhan pakan rusa Bawean. Jenis-jenis tumbuhan tersebut (Tabel 1.) kemudian dikumpulkan untuk dibuat herbarium dan selanjutnya beberapa bagian diambil dibuat preparat epidermisnya.

Rusa Bawean merupakan satwa liar yang selektif dalam memilih pakan (Blouch dan Atmosoedirjo, 1978). Tanda-tanda bekas dimakan jarang terlihat mencolok, hanya bagian-bagian tertentu dari tumbuhan yang menjadi sumber pakannya, dan biasanya dalam jumlah yang sedikit. Tumbuhan yang terindikasi sebagai bekas pakan seringkali harus diperkuat dengan tanda-tanda kehadiran rusa. Seperti antara lain jejak, kotoran dan bekas gesekan tanduk (ranggah) pada tempat bekas pakan diketemukan. Hal ini dilakukan untuk mengurangi kesalahan dalam identifikasi jenis pakan.

\section{Identifikasi pakan dengan analisis kotoran}

Epidermis daun difoto dengan menggunakan mikroskop stereoskopis sebagai acuan identifikasi jenis pakan yang terdapat di dalam kotoran rusa Bawean. Foto epidermis pakan dalam kotoran dibandingkan dengan foto epidermis daun, kemudian dicari kesamaan bentuk, ukuran, pola-pola tertentu (Gambar 2). Indikator lain adalah bentuk derivat epidermis seperti stomata dan trikomata.

Berdasarkan peta sebaran sub populasi rusa Bawean yang menempati tiga kawasan berbeda, yaitu: di Pulau Tanjung Cina, Gunung Besar, dan Gunung Mas (Anonim, 2003a). Berbagai faktor lingkungan, termasuk komponen biotik dan abiotik, menunjukkan perbedaan di setiap kawasan, mungkin mempengaruhi perilaku makan Rusa Bawean. Keadaan ini, mengarahkan pengamatan dilakukan pada ketiga kawasan tersebut. Pengamatan analisis kotoran dilakukan pada musim hujan dan kemarau.

\section{Jenis pakan dominan}

Jenis pakan dominan dalam kotoran Rusa Bawean dinyatakan dengan indeks nilai penting (INP). Nilai ini merupakan hasil penjumlahan dari frekwensi relatif, kerapatan relatif dan dominasi ralatif. Urutan besarnya INP menunjukkan urutan jenis pakan yang dominan.

Data diambil pada musim yang berbeda menujukkan bahwa Rusa Bawean mengkonsumsi pakan dengan dominasi pakan yang berbeda-beda. Fenomena ini ditunjukkan dengan adanya perbedaan INP pada musim penghujan dan musim kemarau. Demikian juga berdasarkan letak kawasan menunjukkan dominasi pakan yang berbeda pula.

\section{Kawasan Pulau Tanjung Cina musim penghujan}

Pada musim penghujan dominasi jenis tumbuhan pakan ditunjukkan oleh jenis taliata (INP: 54,332); Tali oar (INP: 48,945); Gadung (INP: 37,722); Jenis Z (INP: 35, 761); dan Tali susu (INP: 30,470). Jenis-jenis tersebut paling sering ditemui dalam kotoran dibandingkan dengan jenis yang lain.

\section{Kawasan Pulau Tanjung Cina musim kemarau}

Pada musim kemarau jenis pakan yang sering ditemui dalam kotoran adalah Taliata 
(INP: 91, 61); Gadung (INP: 38,44) Tali oar (INP: 33,61); Ilalang (INP: 28,34); dan jenis z (INP: 27,68).

\section{Kawasan Gunung Besar musim penghujan}

Jenis pakan yang sering diketemukan dalam kotoran yang ditemukan di kawasan Gunung Besar pada musim penghujan adalah Ilalang (INP: 144,94); Jenis Z (INP:39, 19); Lambu merah (INP: 36, 36); Lampedung (INP: 26, 67); dan Lating-latingan (INP: 16, 28).

\section{Kawasan Gunung Besar musim kemarau}

Musim kemarau jenis yang sering ditemui dalam kotoran adalah Ilalang (INP: 87, 55); Jenis W (INP: 55, 97); Taliata (INP: 38, 38); Jenis Z (INP: 18, 88); dan Pele (INP: 16, 74). Imperata cylindrica (Ilalang) merupakan jenis yang paling sering dijumpai dalam kotoran Rusa Bawean.

\section{Kawasan Gunung Mas musim penghujan}

Beberapa jenis pakan yang sering dijumpai dalam analisis kotoran yang diketemukan di kawasan Gunung Mas, pada musim penghujan antara lain Jenis Z (INP: 51, 43); Lambu merah (INP: 37, 67): Taliata (INP: 30, 40); Ilalang (INP: 28, 83); dan Talisusu (INP: 28, 49).

\section{Kawasan Gunung Mas musim kemarau}

Pada musim kemarau, berbagai jenis tumbuhan yang dijumpai dalam kotoran Rusa Bawean, antara lain Jenis W (INP: 49, 45); Andudur (INP: 48, 95); Taliata (INP: 48,62); Jenis Z (INP: 45, 25); Lambu merah (INP: 22,97); dan Ilalang (INP: 22,92).

Satwa liar, demikian juga Rusa Bawean dalam memilih sumber pakan mungkin dipengaruhi antara lain oleh keadaan sumber pakan dan juga kebutuhan pakan yang harus dipenuhi (Hansen et al., 2001). Bagian tumbuhan yang dimakan oleh Rusa Bawean adalah pucuk daun dan tunas, fenomena ini dapat dibuktikan dengan bekas-bekas gigitan rusa pada bagian-bagian tumbuhan yang dimakannya.

Kesukaan satwa terhadap struktur dan komposisi tumbuhan tertentu diperlihatkan dalam penggunaan ruang di daerah sumber pakan (feeding ground). Keadaan ini dibuktikan dengan penggunaan tempat-tempat yang memiliki jenis-jenis pakan yang disukai oleh rusa Bawean, seperti di kawasan Pulau Tanjung Cina, Gunung Besar dan kawasan Gunung Mas. Perilaku pemilihan seperti itu, mungkin dalam usaha satwa liar mendapatkan sumber pakan yang lebih baik (Jacques et al., 2006).

Tabel 1. Jenis pakan Rusa Bawen berdasarkan pengamatan bekas atau sisa gigitan.

\begin{tabular}{|c|c|c|c|}
\hline No. & Famili & Nama Ilmiah & Nama Daerah \\
\hline 1. & Graminiae & Imperata cylindrica & Ilalang \\
\hline 2. & Menispermaceae & Pericampylus glaucus & Ancucu \\
\hline 3. & Palmae & Caryota mitis & Andudur \\
\hline 4. & Dioscoreaceae & Dioscorea hispida & Gadung \\
\hline 5. & Symplocaceae & Symplocos edenophylla & Kayu sape \\
\hline 6. & Graminiae & Coelorhachis muricata & Lampedung \\
\hline 7. & Сyperaceae & Scheria hebecarpa & Lanting-lantingan \\
\hline 8. & Graminiae & Paspalum cunjugatum & Lambu merah \\
\hline 9. & Convolvulaceae & Argyera mollis & Rombok putih \\
\hline 10. & Schizaceae & Lygodium circinnatum & Tali ata \\
\hline 11. & Graminiae & Panicum cordatum & Tali oar \\
\hline 12. & Nephrolepis & Nephrolepis hirsitula & Rendang-rendang \\
\hline 13. & Compositae & Tridax procumbens & Kenci-kencian \\
\hline 14. & Graminiae & Brachiaria distachya & Kabak-kabakan alas \\
\hline 15. & Сyperaceae & Fimbrisyllis dichotoma & Lente-lentean \\
\hline 16. & ------------------- & -------------------- & Tali susu \\
\hline 17. & ---------------------- & --------------------- & Pele \\
\hline
\end{tabular}




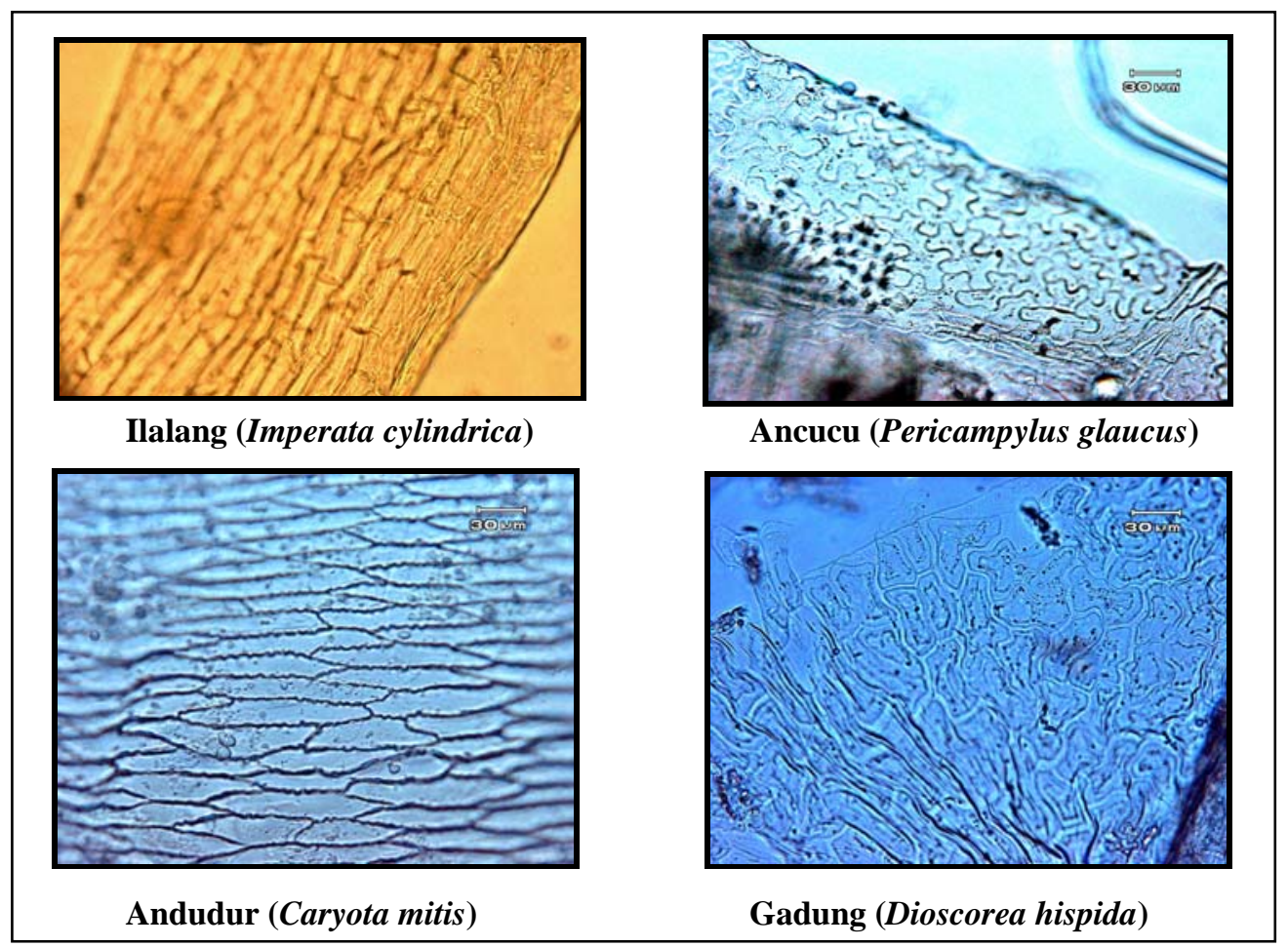

Gambar 2. Contoh epidermis daun pakan Rusa Bawean ditemukan di lapangan.

\section{Kesimpulan dan Saran}

\section{Kesimpulan}

Dari penelitian ini dapat disimpulkan bahwa: berdasarkan pengamatan bekas atau sisa gigitan dan analisis kotoran, diketahui jenis-jenis pakan Rusa Bawean antara lain: Ilalang (Imperata cylindrica), Ancucu (Pericampylus glaucus), Andudur (Caryota mitis), Gadung (Dioscorea hispida), Kayu sape (Symplocos adenophylla), Lampedung (Coelorhachis muricata), Lating-latingan (Scheria hebecarpa), Lambu merah (Paspalum conjugatum), Rombok putih (Argyera mollis), Taliata (Lygodium circinnatum), Tali oar (Panicum cordatum), Rendang-rendang (Nephrolepis hirsitula), Kenci-kencian (Fimbrisyllis dichotoma), Tali susu dan Pele. Sementara itu, terdapat jenis tidak dapat diidentifikasi, antara lain, jenis $\mathrm{X}$, Jenis $\mathrm{W}$, Jenis Z, Jenis U, dan Jenis Y. Tiga jenis pakan dominan Rusa Bawean pada musim penghujan antara lain; di Pulau Tanjung Cina: Taliata (INP: 54, 33), Talioar (INP: 48, 94), dan Gadung (INP: 37, 72); di kawasan Gunung
Besar: Ilalang (INP: 144, 94), Jenis Z (INP: 39, 19), dan Lambu merah (INP: 36,36); di kawasan Gunung Mas: Jenis Z (INP: 51, 43), Lambu merah (INP: 37,67), dan Taliata (INP: 30,39). Musim kemarau, di Pulau Tanjung Cina: Taliata (INP: 91,61), Gadung (INP: 38, 44), dan Talioar (INP: 33, 61); di kawasan Gunung Besar: Ilalang (INP: 87, 55), Jenis W (INP: 55, 97), dan Taliata (INP: 38, 38); di kawasan Gunung Mas: Jenis W (INP: 49, 45), Andudur (INP: 48, 95), dan Taliata (INP: 48, 62).

\section{Saran}

Informasi jenis-jenis pakan, alami dan pakan dominan rusa Bawean perlu dilakukan beberapa kegiatan seperti: 1). Pemantauan persebaran populasi rusa Bawean secara periodik, guna mengetahui keadaan pakan di habitatnya. 2). Kajian kualitas pakan seperti analisis proksimat, untuk mengembangkan jenis-jenis pakan guna mendukung kebugaran populasi rusa Bawean. 


\section{Daftar Pustaka}

Atle, M., Langvatn, R., Yoccoz, N.G. and Stenseth, N.C. 2001. Plant phenology, migration and geographical variation in body weight of a large herbivore: the effect of a variable topography. J. of Animal Ecology 70: 915-923.

Anonim. 2003a. Laporan Studi Ekologi Rusa Bawean (Axis Khuhlii), sebaran dan kelimpahan populasi Rusa Bawean. Kerjasama antara BKSDA Jatim I dengan Fakultas Kehutanan Universitas Gadjah Mada. Surabaya. Tidak dipublikasikan.

Anonim. 2003b. Laporan Studi Ekologi Rusa Bawean (Axis khuhlii) Tentang Tipe-Tipe Habitat Rusa Bawean. Kerjasama antara BKSDA Jatim I dengan Fak. Kehutanan Universitas Gadjah Mada. Surabaya. Tidak dipublikasikan.

Blouch, R.A. and Atmosoedirdjo, S. 1978. An indirech approach to obtain Bawean Deer population data. In: Jeffrey, A.M., Rabor, D.S. and Sumardja, E.A. (Eds.). SEAMEO Regional Center for Tropical Biology. pp 93-97. In Proc. of the Biotrop Symposium on Animal Populations and Wildlife Management in South East Asia.Bogor.

Bhadresa, R. 1981. Identification of leaf epidermal fragment in rabbit faeces (with reference to heatland vegetation). Rogate Field Centre, Rogate Petersfield. King's College London.

Bolen, Eric, G. and Robinson, W.L. 1995. Wildlife ecology and management. Prentice Hall. Englewood Clifts. New Jersey.

Benson, D.E. 2003. Wildlife as a farm and ranch business. Colorado State University Cooperative. Extension. 11/98. www. Ext. Colostate.edu. 04/07/2008.

David, J.M. 1962. Analysis of sheep diet utilizing plant epidermal fragments in faeces samples. Grazing in terrestrial and marine environments. Symposium of The British Ecological Society, Bangor 11-14 April. Edited by D.J. Crisp Phd. Blackwell Scientific Publications. Oxford. 173-187.

Djuwantoko. 1994. Kajian Tentang Kompetisi Pakan Herbivora Dengan Pendekatan Analisis kotoran. Fakultas Kehutanan Universitas Gadjah Mada Yogyakarta. Tidak dipublikasikan.

Graham, K.L. 2002. Human influences on forest wildlife habitat. US Fish and Wildlife Service. 63-90. Southern Forest Resource assessment. In: David, N. and Greis, J.G. (Eds). Ge. Tech.SRS-53. Asheville. NC: US Department of Agriculture, Forest Service, Southern Research Station.
Gray, S., Schwertner, T.W. and Simpson, R. 2007. Diet composition greater kudu at Mason Mountain WHA.Texas Park and Wildlife Department, 4200 Smith School Road, Austin.

Hercus, B.H. 1960. Plant cuticule as an aid to determining the diet of grazing animals. Proc. Int. Grass. Congress. pp 443-445.

Heyne, K. 1987. Tumbuhan Berguna Indonesia. Jilid III. Penerbit Yayasan Sarana Wana Jaya. Jakarta.

Hansen, M.C., Yoakum, J.D., Pyle, W.H. and Anthony, R.G. 2001. New strategies for pronghorn food habit studies. Proceeding of the Biennial Pronghorn Antelope Workshop. 19: 71-94.

Jacques, C.N., Sievers, J.D., Jenks, J.A., Sexton, C.L. and Roddy, D.E. 2006. Evaluating diet composition of pronghorn in Wind Cave National Park, South Dakota. The prairie naturalist 38 (4): 301-312.

Junsheng, Li., Wu Jianping and Jiang Zhao Wen. 2008. Food habits and selective grazing of Mongolian Gazelle (Procarpra gutturosa) in Hulunber Grassland. J. of forestry research 10 (3): 187-190.

Kurose, N., Masuda, R. and Tatara, M. 2005. Fecal DNA Analysis for identifying species and sex of sympatric carnivores: Noninvasive method for conservation on the Tsushumia Island, Japan. Oxford Journal Life Science. J. of Heredity 96 (6): 688-697.

Mcinnis, M.L., Vavra, M. and Krueger, W.C. 1983. A comparison of four methods used to determine the diets of large herbivours. J. of range managements 36 (3): 32-37.

Padmalal, K.U.K.G. and Takatsuki, S. 1993. Comparison of the botanical composition of the rumen and Fecal contents Sika deer on Mt. Goyo. The J. of Mammalogical Society 18 (2): 99-104.

Storr, M.G. 1961. Microscopic Analysis of Feces, A Technique for Acertaining the Diet of Herbivorous Mammals. J. Biological Science 14 (1): 157-163.

Stewart, D.R.M. 1967. Analysis of plant epidermis in faeces: A technique for studying the food preferences of grazing herbivore. $J$ of Applied Ecology 4: 83-111.

Takatsuki, S. 1978. Precision of fecal Analysis. A Feeding Experiments with Penned Sika deer. Biological Institute, Faculty of Science. Tohoku University Sendai, Miyagi. J. of Mammalogical Society 7 (4): 167-188. 